\title{
Familial prostate cancer
}

INSERM

\section{Source}

INSERM. (1999). Orphanet: an online rare disease and orphan drug data base. Familial prostate cancer. ORPHA:1331

Familial prostate cancer (FPC) is a malignant tumor of the prostate with an early onset. FPC is either asymptomatic or causes mictionary symptoms, erectile dysfunction, bone pain, venous compression and infectious or inflammatory syndrome (for the metastatic forms). It is also characterized by familial antecedents. 